Богдан Дражета

Институт за етнологију и антропологију Филозофски факултет, Универзитет у Београду

drazetab@gmail.com

\title{
Љубица Милосављевић
}

Одељьее за етнологију и антропологију Институт за етнологију и антропологију Филозофски факултет, Универзитет у Београду

ljmilosa@f.bg.ac.rs

\section{Радно време и нове организационе вредности као показатељ убрзања српског друштва током друге деценије XXI века: антрополошка анализа}

Апстракт: Рад има за циљ да преиспита доживљај процеса убрзања времена код запослених у канцеларији једне мултинационалне компаније у Београду на основу резултата теренског истраживања спроведеног 2015. и 2016. године. Научни фокус постављен је на радно време и карактеристичне темпоралне међе које га одређују, а као најзначајнији резултат ваља издвојити тај да је доживљај датог феномена резултат чињенице да време проведено у раду све више потискује приватно време испитаника, готово, до тачке потпуне узурпације. Процес убрзања времена анализиран је на три нивоа на основу исказа педесет шест испитаника. Први ниво подразумевао је анализу поштовања пословне сатнице; други је био оријентисан ка проучавању процеса и периода њиховог прилагођавања иностраним колегама; док је трећи ниво анализе имао за циљ да упути у однос упосленика према радном времену пре и након искуства рада са иностраним колегама. Овакав дизајн истраживања испоставио се као најподеснији ако се има у виду да се резултати овог истраживања наслањају на резултате антрополошког истраживања из 2005. године које је за циљ имало преиспитивање доживљаја, стратегија и очекивања у погледу радног времена тридесет запослених Београђана различитих радних позиција, пословних оријентација и дужина каријере код којих је детектовано замагљивање разлика између пословне и приватне сфере живота, услед искуства рада у промењеном социоекономском и политичком контексту почев од 2000. године и започињања реформског процеса придруживања ЕУ које је пратило специфично друштвено убрзање. Продужетак ових процеса, уз одрећене значајке које долазе и као резултат још једне промене политичке климе у земљи 2012. године, због тога, јесу кључне потке кроз које ће бити сагледаван феномен убрзања времена у савременом српском друштву на примеру конкретне радне заједнице.

Кључне речи: пословна антропологија, антропологија времена, друштвено убрзање, радно време, упосленици, мултинационална компанија 
Феномени којима заједнице људи из пословног света придају различита значења у оквиру различитих радних окружења, могу се проучавати легитимно као и свака друга тема у етнологији и антропологији. Један од примера јесте и проучавање доживљаја убрзања времена, на основу теренског истраживања из 2005. године - чији су резултати објављени у одвојеном прилогу - које је за циљ имало преиспитивање доживљаја, стратегија и очекивања у погледу радног времена и појединих темпоралних међа које га дефинишу на основу анализе наратива тридесет Београђана који су били запослени у различитим радним организацијама, било да су се разлике односиле на врсту делатности или да се радило о подвајању између тзв. друштвеног и приватног сектора који се постепено увећавао и у случају домаћег, мешовитог или иностраног оснивачког капитала (Milosavljević i Dražeta 2021). У овом чланку, који у извесној мери представља наставак поменутог прилога, следствено ће бити представљени и интерпретирани одговори педесет шест испитаника, запослених у представништву једне мултинационалне компаније у Београду, у вези са њиховим радним временом, овога пута, с циљем указивања на наставак процеса раније детектованог убрзања које се најпре кретало од замагљивања разграничења између приватне и пословне сфере живота 2005. године, да би ове границе у истраживању спроведеном 2015. и 2016. године биле готово потпуно поништене, према исказима испитаника. Из апострофираних разлога, овај прилог, као и претходни, бива постављен у оквире две антрополошке поддисциплине - пословне, односно организационе антропологије којој ће у наставку бити посвећено више пажње, и антропологије времена којој је у већој мери посвећен претходни прилог (о антропологији времена више у: Milosavljević i Dražeta 2021, 76-79).

У контекстуалном смислу, истраживање прати наставак процеса друштвеног убрзањ $a^{1}$ на средини друге деценије XXI века након друштвених, економских и политичких промена 2000. године, када је Србија ушла у процес приватизације и макроекономске стабилизације, који се одвијао убрзано, а све са циљем привредног раста и паралелног развоја приватног сектора (о друштвеном убрзању на конкретном примеру више у: Milosavljević i Dražeta 2021). Управо у овом периоду дошло је до појаве већине мултинационалних компанија, док је предузетницима дат подстрек да започну своју борбу на тржишту (Vučinić-Nešković 2010). Још од шездесетих година XX века може се пратити настанак мултинационалних компанија на глобалном нивоу, са циљем стварања транснационалне привреде и проширења тржишта изван националних граница (Ribić 2011, 169-170), а након што су деведесете годи-

${ }^{1} \mathrm{O}$ друштвеном убрзању биће више речи у наставку рада. 
не XX века означиле крај преимућства друштвеног сектора, када се јављају „нови трендови“, „нови видови“ и „нови актери“ у „сфери рада“ у Србији (о измењеној сфери рада више у: Bolčić 2002, 79-108). Промене у оквиру економије у Србији на почетку XXI века, сходно започетим политичким и друштвеним променама, показивале су да је у Србији постојала све већа упућеност привреде и друштва ка политичко-економској сарадњи у оквиру међународне заједнице (Мојić 2010, 3), што ће бити могуће показати и овим прилогом на примеру упосленика који имају контакте са странцима у оквиру једне такве међународне организације.

Поред реформи у области макроекономије и монетарне политике, исте су настављене приликом реструктуирања банкарског сектора, као и реформи спровођених у домену правосуђа и дипломатије (Naumović 2006, 110). С тим у вези, нови концепти као што су флексибилна каријера без граница, лични и професионални развој појединца за обављање различитих радних задатака у различитим контекстима, почињу да замењују традиционалну каријеру, тј. линеарно напредовање појединца у једној организацији спрам доступних, хијерархизованих позиција у организацији (Rifkin 2005). Међутим, ваља подсетити и на то да апострофиране промене многе појединце затичу и на средини или на крају већ потврђених каријера када процеси прилагођавања спољним утицајима могу подразумевати активацију другачијих механизама од оних који су на делу код упосленика који тек улазе на тржиште рада или су на њему краћи временски период.

С друге стране - најшире гледано - политички, економски, друштвени и културни услови у свету све више бивају обликовани процесом глобализације која обухвата друштвене, економске, културне и демографске процесе ван оквира нација (Kearney 1995, 548). Последица такве друштвене денационализације је проточност робе, средстава плаћања, штетних материја, информација и људи (Ribić 2007a, 241), чему је могуће додати и начине на који се вреднује и размерава време предвиђено за рад, насупрот времену које би требало да припада домену доколице и одмора. Мичел Сеџвик, даље, дефинише глобализацију као „исход, или предмет брзих промена у вези са друштвеним, технолошким, политичким и економским аренама које су раније деловале мање проходно“ (Sedgwick 2007, 3), ${ }^{2}$ док се апострофирана брзина може уочити и на примеру одабраном за проучавање код којег

2 Ипак, треба имати на уму да је ситуација по питању пандемије Ковида 19 довела до одређеног „заокрета“. Процес глобализације се, наиме, у овом тренутку огледа у све већем протекционизму сопствених привреда који практикују велике државе, што се може подвести под термином „деглобализације“. Овакве поставке захтевале би нова истраживања када је реч о убрзању српског друштва на примеру радних средина, будући да је проточност робе, информација и људи у Србији значајно измењена у периоду од марта 2020. до априла 2021. године. 
се, такође, бележи убрзање (о ранијим фазама везаним за домаћи контекст више у: Milosavljević i Dražeta 2021). У оквиру таквог поретка доминантни политички, друштвени и економски миље јесте неолиберализам, у коме се благостање човека посматра кроз развој личних слобода и вештина, развој приватне својине, слободног тржишта и слободне трговине (Harvey 2005, 2). За овакав пут определила се и Србија након 2000. године, када су отворена представништва великог броја мултинационалних компанија, што је било праћено и приватизацијом државних фирми, страном финансијском помоћи и другим променама (Vučinić-Nešković 2010, 271-272) У оквиру наведених поставки, у најкраћем, започиње „интензивнији контакт домаћег радног корпуса са људима који долазе из другачијих професионалних традиција“ (Milosavljević i Dražeta 2021, 76), што ће даље утицати на више планова када су у питању запослени у мултинационалној компанији. Један од њих тиче се централне теме овога рада која се протеже од пословног до приватног времена упосленика који углавном започињу, а у мањој мери настављају, властите каријере у условима које карактеришу вишеструке социоекономске и политичке промене. Управо те промене, међутим, нису исцрпљене оријентацијама с почетка новог века, него бивају настављене и у каснијем периоду наступајућом политичком променом.

Променом власти 2012. године, наиме, економски пут Србије трасиран је на горенаведеним основана, уз оцену да жељени ефекти привредног преображаја земље нису постигнути, због чега је наступило стање тзв. „транзиционе замке“ у којој спроведене реформе не дају резултате јер се уводе недоследно, неефикасно и споро. Пословно окружење за многобројне компаније и предузећа није постало повољно како је очекивано, у периоду од када су реформе на почетку столећа започете (Krstić, Fedajev i Nikolić 2017, 186-187). Штавише, усмерење ка увећавању сектора услуга науштрб индустријске производње и потенцијала прерађивачке индустрије показало се неефикасним не само у доба светске економске кризе 2008, већ и током друге деценије 21. века (Savić i Đerasimović 2020, 34). Управо у оваквим условима спроведено је и потоње антрополошко истраживање које ће на овом месту бити детаљно представљено и, накнадно, контрастирано са резултатима истраживања из 2005. године.

\section{Теоријска основа истраживања}

Као што је у претходном прилогу наведено, организације, предузећа и компаније било каквог обима могу бити погодне за истраживање јер представљају групе запослених упућених једни на друге, ,a чија се повезаност не ограничава само на радно време“" (Milosavljević i Dražeta 2021, 79). Грег 
Урбан и Кјунг-Нан Кох сматрају да се модерне пословне корпорације могу истраживати изнутра попут традиционалних друштава и других малих заједница, или као делатници који утичу на промене у свету (Urban and Koh 2013, 140), што је видљиво и када је реч о феномену времена. Међутим, ова два приступа имају могућност да сарађују путем дијалога, а то антропологија може омогућити као дисциплина. Она је временом доказала, на основу етнографских истраживања, да су корпорације друштвене групе „са својим интерним митовима, ритуалима, веровањима, нормама и праксама" (Urban and Koh 2013, 141). Док са једне стране постоје етнографије за корпоращије које су спровели запослени или пак примењено оријентисани антрополози, с друге стране постоје етнографије у корпоращијама, које су урадиле њихове академске колеге. У прве спадају студије радног места и истраживање потрошача, док се друге баве варијацијама корпоративних облика, наративима и праксама, културном рефлексивношћу и променама. Етичка питања постављају се непрекидно током етнографских истраживања, а најважније је да добијени подаци не буду злоупотребљени од стране руководиоца у компанији или шире јавности. Држање до научних принципа зависиће од тога да ли антрополог посматра корпорације као деструктивне по људе и околину или као агенте друштвеног бољитка (Urban and Koh 2013, 143-153).

Пословна антропологија се посматра као антрополошко поље са „теоретском и интелектуалном зрелошћу“ (Baba 2006, 37). Може се рећи да овај чланак припада наведеној антрополошкој поддисциплини, на основу тога што се бави ставовима и размишљањима упосленика, тј. проучава заједницу људи у оквиру пословног света. Научна продукција из поља пословне антропологије је готово у потпуности присутна у оквиру англоамеричког говорног подручја, што показује да је у оквиру тамошњих научних заједница јаче интересовање у вези с истраживањем рада, организацијама и сл. Пословна антропологија обухвата организациону антропологију, мада се обе кованице често појављују у литератури. Пословна антропологија (business anthropology) је почела да се употребљава током осамдесетих година прошлог века као синтагма коју су створили антрополози који су радили ван академске средине, а проучавали су понашање потрошача и маркетинга. У савремено доба, међутим, ово поље обухвата било какву примену антропологије приликом решавања пословних проблема (Baba 2006, 1; Milosavljević i Dražeta 2021, 80). Пословна антропологија се може дефинисати кроз три поља антрополошког проучавања у оквиру приватног сектора. У питању су организациона, дизајнерска и потрошачка антропологија. Организациона антропологија настоји да истражи унутрашњост компаније и анализира људе и групе који чине радну снагу одређене организације. Дизајнерска антропологија проучава дизајн нових производа, услуга и система намењених различитим корисницима, док је потрошачка 
антропологија повезана са понашањем потрошача на местима где се потрошња одвија (Gray 2009, 1).

Антропологија је као дисциплина била присутна од самих својих почетака током различитих историјских периода када је у питању проучавање трговине, рада и односа између институција и људи уопште. О томе је опширније писано на другом месту (Baba 2006, 1-23). Историјат пословне антропологије почиње са Хоторн експериментом, ${ }^{3}$ мада је њено академско утемељење почело много касније. Различите идеје и концепти у вези са проучавањем рада и заједница људи у пословном свету биле су присутне али нису биле јасно конципиране у оквиру одређеног антрополошког поља (Baba 2012, 24-25). Проучавати пословни свет и бити антрополог јесте „дупли изазов“ из академске тачке гледишта, будући да су вредности академске и пословне средине често у супротности. Због тога идентитет пословне антропологије не зависи само од академског образовања него и других фактора чији је утицај на истраживача неспоран (Batteau and Psenka 2012, 81-82). Постоји мишљење да ће се из године у годину све више истраживача бавити пословном антропологијом (Guang and Tian 2014, 1). Оно што њих раздваја од осталих научника који се баве наведеним феноменима јесте, пре свега, методологија. Заједнице мањег обима проучавају се путем дугорочног теренског рада, сакупљају се различити подаци и користи посматрање са учествовањем, уз квалитативне интервјуе (Lewis 1999, 3).

Организациона антропологија припада ширем домену пословне антропологије, док је свако додавање придева произвољно према истраживању које се спроводи. Постоји још других назива које употребљавају антрополози као што су „индустријска антропологија“, „корпоративна антропологија“, ,антропологија предузећа“, „,антропологија рада“, „,антропологија менаџмента“, као и „економска антропологија“. Чак се сматра да је организациона антропологија заправо таутологија јер је она као дисциплина одувек проучавала начине људског организовања, због чега је придев

3 Хоторн експеримент је изведен са намером „повећања продуктивности радне снаге“, кроз смањење умора и незадовољства радника у компанији „Western Electric“ код Чикага током двадесетих година XX века. Осим других друштвених научника, руководилац пројекта Елтон Мејо познавао је Бронислава Малиновског и Алфреда Реџиналда Редклиф-Брауна, па је ангажован један од њихових студената Вилијам Лојд Ворнер. Он се прикључио у завршној фази пројекта са намером да изучи „шта су радници заправо радили на послу, у супротности са оним што су говорили током интервјуа“. Налази нису били у складу са рационалном менаџерском теоријом и концепцијом економског човека јер су указивали да радници, у складу са својим потребама и жељама, стварају и одржавају вредности, ставове и понашања који нису у спрези са ониме што руководство пропагира. Тако је рођена неформална теорија менаџмента, а две деценије касније и Школа људских односа (Human Relations School) (Baba 2006, 3-7; Ribić 2007b, 81-94). 
„пословна“ знатно прецизнији (Moeran and Garsten 2012, 2-3). Један од ставова у дискусији одржаној на ову тему био је да се антрополози пре баве антропологијом у организацијама, него организационом антропологијом због тога што је „целокупна антропологија, на неки начин, студија о томе како се људи организују“ (Lloyd 2008). Иако су слични по темама истраживања, организациона антропологија и организационо понашање су се као дисциплине удаљиле током периода од неколико деценија једна од друге, иако су током својих почетака биле узајамно повезане (Bate 1997, 1148). Стивен Робинс сматра да је организационо понашање мултидисциплинарна област која изучава „ставове и дејства људи које они испољавају унутар организације“" (Robbins 2005, 2-4). Ова дисциплина примењеног и бихејвиоралног карактера користи одреднице и теорије из психологије, социологије, социјалне психологије, антропологије и политичких наука (Robbins 2005, 2-4). Организације које антрополози проучавају не морају само бити корпорације, већ мала и средња предузећа, невладин сектор, као и медицинске, индигене (домородачке) и виртуалне организације (Jordan and Caulkins 2013, 2-9).

Иницијални допринос у области организационе антропологије у оквиру домаће науке дала је Дуња Рихтман-Аугуштин, уочивши да су вредности те које обележавају подједнако спољашњи (друштвено-политички систем) и унутрашњи (саму организацију, тј. културу организащије) контекст у коме предузеће делује. За њу су комплекси појава везани за културу испреплетани са истим таквим комплексом везаним за друштво, те је због тога неопходно најпре одредити доминантне вредности уопште, јер су оне заједничко поље ових двају појмова. Бавећи се особинама традицијске културе на просторима где су живели народи који припадају широј наднационалној групи Јужних Словена, тј. ониме што назива „прединдустријском руралном културом“, ауторка жели да напомене да је неопходно узети у обзир те историјске чињенице како би се сагледао садашњи модел индустријске културе. Колико ће се радник или било који запослени поистовећивати са својим предузећем зависиће од случаја до случаја, што је „стварна вриједносна оријентација“ насупрот „идеалној“. На тај начин могу да се уочавају и истражују промене у вредносном систему појединаца (Rihtman-Auguštin 1970, 5-19). Указивање на тадашње савремене проблеме с краја седамдесетих година XX века, као што су преношење појединих традиционалних образаца у урбани контекст, доказује да је ова ауторка уочила да породичне, професионалне и друге заједнице у којима појединац обитава могу бити предмет етнолошког истраживања (Rihtman-Auguštin 1980, 64-65).

Као што је наведено, Рихтман-Аугуштинова сматра важним спољни утицај околине, тј. друштва и културе чији се утицај преноси на мале групе. Међутим, она напомиње да је било који модел друштва проблематичан 
због непоклапања са стварношћу и да постоје заједнице у којима су породични, суседски па и односи на раду нешто што више обликује људе. Дакле, у тим друштвима показује се да тзв. партикуларизми бивају јачи од универзализама, односно средстава масовне комуникације, система образовања, књижевности, науке итд. Стога она тумачи постојање самоуправног радног колектива као социјално-културног система, те даље формулише појам културе подузећа. Управо је то тај горенаведени „унутрашњи контекст“" у коме предузеће делује, овога пута јасно формулисан и илустрован путем четири студије случаја различитих култура предузећа четири различите организације. Потребно је нагласити да је њен чланак у коме је реч о култури предузећа изашао 1972. године, тачније читавих седам година пре првог чланка Ендрјуа Петигруа о организационој култури на западној хемисфери (Milosavljević i Dražeta 2021, 80). ${ }^{4}$ Она је у том чланку навела прерађену и на домаћи контекст прилагођену дефиницију културе предузећа Елиота Жака:

Култура подузећа је уобичајени, традиционални начин како се ствари у подузећу обављају који је својствен, у већој или мањој мјери, свим припадницима подузећа, и који чланови морају научити и барем дјеломично усвојити како би били примљени на посао. Култура у том смислу покрива велики сплет понашања: методе производње; радне способности и вјештине и техничко знање; ставове према дисциплини и казнама; обичаје и навике како се понашају руководиоци; циљеве подузећа; начин како подузеће послује; методе награђивања; важност која се придаје појединим типовима; стварну улогу и утјецај самоуправљања и остале мање свјесне конвенције и табуе. (Rihtman-Auguštin 1972, 124)

Наведену дефиницију је важно приказати у потпуности зато што је прва такве врсте у тадашњој југословенској етнологији и антропологији (Milosavljević i Dražeta 2021, 81). Иако није у потпуности оригинална, она је била примењива на тадашње услове самоуправног социјализма. Међу наведеним студијама случаја, од велике важности за овај рад јесте последња из тог рада, која осликава како традиционална околина утиче на концепцију културе предузећа. Сукоби, корупција и поткрадање у једном предузећу били су описани од стране једног запосленог десетерцем, тј. његовом ауторском песмом, по узору на народне песме. Сви ти примери

4 Култура предузећа или организациона култура као феномен представља „систем претпоставки, вредности, норми и ставова манифестованих кроз симболе, које су чланови једне организације развили и усвојили кроз заједничко искуство и који им помаже да одреде значења света који их окружује и како да се у њему понашају“ (Janićijević 2013, 35). Овим концептом се у Србији највише бавио Небојшња Јанићијевић, будући да је анализирао развој, перспективе и значај организационе културе (Janićijević 1997, 26-46). 
које је ауторка наводила имали су за циљ да укажу на „велике разлике од радног колектива до колектива“ и да би будућа истраживања требала да се крећу у правцу утврђивања нових посебности, константи у културама предузећа, као и типова и структура које се потенцијално могу уочити. Према њој су тадашњи утицаји „културе околине“ били преовлађујући на културу предузећа, што у одређеној мери подсећа на саму тему овог рада. Она се на крају пита „како самоуправни комплекс трансформира културу подузећа“, тј. колико појединачна предузећа успевају да одоле утицајима ширег друштвено економског система (Rihtman-Auguštin 1972, 121-151).

Даљи одзив по питању проучавања културе предузећа, различитих организација и радних односа у тадашњој етнологији био је у складу са методолошким и предметним заокретом који се дешавао у оквиру дисциплине (Kovačević i Antonijević 2014). Проучавање пријема у пионирску организацију (Malešević 1984) или свечаности испраћања радника у пензију (Bratić 1984), указивала је на то да су поједине колеге настојале да иду у корак са временом, проучавајући пословне процесе који су се одвијали претежно у фабрикама као великим индустријским гигантима. Тако је 1986. године у броју 7 часописа Етнолошке свеске делом обрађена тема културе радничке класе. У том смислу, настали су чланци чије су теме биле прослава дана предузећа (Stojković 1986) или ритуализација процеса производње и извоза аутомобила ,југо“ у САД (Antonijević 1986). Управо је то време када испливавају на површину одређени економски и друштвени проблеми, пре свега због неспремности владајућих структура да започну и спроведу промене (Antonijević 2009, 24).

Развој организационе антропологије или етнологије предузећа настављен је 1992. године у Гласнику Етнографског института САНУ када је објављен рад једног француског колеге, од значаја за домаћи контекст. Жан Франсоа-Госјо наводи да етнолози бивају све чешће консултовани и ангажовани од стране носиоца економске и политичке моћи у ,анализирању ентеријера индустријских предузећа“. Међутим, обично они који наручују истраживања захтевају да имају резултате истих у што краћем временском року. Аутор наводи да је сврха етнологије у предузећима и организацијама побољшање комуникације и међуљудских односа, тј. очување „културе предузећа“, чију „употребну сврху“ етнолог треба да докаже као „специјалиста за културе“. Потом наводи два лична етнографска примера где је доказао да етнолог не може бити „специјалиста за проблеме група“ (попут социолога и психолога) уколико не укључи шири контекст „властитог друштва“ у своје истраживање. Његова улога је да укаже да на такве мање групе, каква је култура неког предузећа, утичу првенствено породица, шира друштвена заједница па и само друштво. Етнолог нема више улогу краљевог саветника, већ краљеве луде која разоткрива митове и ме- 
ханизме власти у својој заједници. Етнолози могу да проучавају пословне заједнице које имају сопствене културе, тј. системе вредности и понашања (Gossiaux 1992, 213-220).

У XXI веку је српска етнологија и антропологија препознала одређени опсег тема из пословног света, пре свега кроз Dioscuri пројекат (2004-2007.) чији је основни циљ био уочавање и проблематизовање културних додира Запада и Истока у економији и друштву Европе након 1989. године, тј. пада Берлинског зида. Дакле, циљ је био видети колико се нови друштвено економски поредак „усталио“ у земљама источне Европе. Постојала је свест да ће ти „судари култура“ бити присутни и на пословном плану односно између две или више пословне и организационе културе (Erdei 2011, 60). Пројекат је обухватао истраживачке тимове из Аустрије, Бугарске, Чешке, Хрватске, Пољске, Румуније, Словеније и Србије и Црне Горе (VučinićNešković 2011, 17-19; Вучинић-Нешковић 2013, 24). Деветочлани тим из тадашње Србије и Црне Горе, којим је руководила Весна Вучинић Нешковић, био је сачињен од стручњака из области антропологије, социологије и економије. Антрополошки радови бавили су се пословном културом Хаузмајстора, фирме која је обављала мале кућне поправке, а основао ју је српски повратник из иностранства (Vučinić-Nešković 2010, 2011, 2012). Истраживачке теме су биле спровођење аграрних реформи и утицај домаће културе на пословање једног породичног предузећа (Naumović 2006, 2013), као и проучавање друштвених последица приватизације панчевачке пиваpe (Erdei 2011). Медијска пропраћеност приватизације компаније „Књаз Милош“ (Vučinić-Nešković and Miokov 2011) и комбиновање савремених пословних и традицијских пракси код предузетника у књажевачком крају (Erdei 2009), још неке су од тема. Владимир Ж. Миоков у свом магистарском раду бавио се анализом пословне културе коју стварају менаџери као припадници одређене културе, доказавши да је „пословна култура заправо део општег, ширег система културних вредности“. Поред тога, нагласак је на томе да се не смеју доносити судови у вези са тиме који је систем „бољи“ или „лошији“, већ се само могу анализирати њихове специфичности, без вредносних конотација (Miokov 2008, 126-129). Допринос пољу пословне, односно организационе антропологије представљају како ово истраживање, рађено у периоду од 2015. до 2016. године, тако и овај чланак, и то као емпиријско утемељење, попут претходног истраживања спроведеног 2005. године и раније презентоваих ретултата (више у: Milosavljević i Dražeta 2021).

Истовремено, истраживања из 2005. и 2015. и 2016. године, поред тога што представљају домаће примере бављења пословном антропологијом, представљају и прилоге антрополошком проучавању феномена времена с посебним нагласком на аспекте убрзаља (детаљније разраде изнете су и 
у претходном прилогу: Milosavljević i Dražeta 2021, 76-79). Антрополошко бављење временом, у најкраћем, најчешће је било под окриљем других проучаваних проблема и наглашавало је потребу бављења временом у релацији са радњом, учесницима у радњи и местом извођења радње што бива појачано и тврдњом да су време и простор интегрисани једно у друго (Munn 1992, 94). Радно време, стога, постаје нарочито подесно за истраживање будући да је дефинисано као време „када је запослени дужан да извршава радне задатке делегиране од стране послодавца“ као и то да „битна одредница за одређивање појма радног права јесте фиксирање места рада током радног времена, у просторијама послодавца или другом месту где се послови обављају“ (Rajić Ćalić 2018, 186). Међутим, поред тога што га омеђавају мање или више јасно дефинисане временске и просторне границе, за антрополошко поимање радног времена важно је нагласити и то да оно „може бити сагледавано и кроз одступања и поклапања са формално прописаним, али и додатно пребојеним личним доживљајима који, пак, могу зависити од различитих фактора и процеса, друштвених и индивидуалних“ (Milosavljević i Dražeta 2021, 77). Следствено, као изразито значајан за разумевање проблема изабраног за проучавање намеће се процес друштвеног убрзања, који Хартмут Роза схвата као производ модернизацијских процеса износећи почетну хипотезу према којој је „искуство модернизације искуство убрзања““ (Rosa 2013, 21) с нагласком на то да поступак друштвене акцелерације траје већ готово триста година (Roza $2019,15)$. Теза коју аутор заступа може се појаснити стајалиштем ,да је искуство модерности и модернизације у свим својим фазама и на свим местима својег манифестовања увек било и јесте искуство динамизације и убрзавања повести, друштва, културе, живота и/или чак самог времена“ (Roza 2019, 209). У оквиру њега, као један од значајнијих императива ваља издвојити захтев за синхронизацијом будући да ми као појединци готово никада не одређујемо ритам, брзину, трајање и след наших активности, него их готово увек прописују колективни темпорални обрасци и захтеви за синхронизацијом које намеће друштво (Rosa 2013, 9). Другим речима, преостаје нам једино то да „наше акције непрестано морамо оријентисати према комплементарним активностима и временским обрасцима наших партнера у интеракцији, те да морамо обезбедити макар и привремену синхронизацију“ (Rosa 2013, 10) што нарочито постаје важно у домену пословног живота појединца, тим пре ако се као генерално пожељно разуме убрзање процеса управљања према циљевима (производња робе, коришћење транспортних рута или проток информација) (Rosa 2013, 17).

На овом месту, биће детаљније упућено у три форме убрзања које аутор издваја као најмерљивије с циљем бољег разумевања етнографских података чија анализа следи у наставку, али и „одређивања процеса 
модернизације као процеса континуираног, и такорећи, 'тродимензионалног’ друштвеног убрзања“" (Roza 2019, 209). Аутор, тако, издваја: техничко убрзање, убрзање друштвених промена и убрзање темпа живота (више и y: Rosa 2013, 97-148; Wajcman 2015, 16):

Прича о високом темпу модерног друшва (то јест савременог друштва), наиме, може се као прво односити на све већу брзину техничких процеса (као што су кретање, комуникација или производња добара), и друго, може да има на уму високе стопе друитвене промене (рецимо темпо којим се мењају модни трендови, партнери у одређеним периодима живота, или владе), или, треће, може да се усмери на осећај недостатка времена који произилази из потребе да се уради или да се мора урадити више ствари у краћем времену, те да се због тога појачава темпо живота или делања. (Roza 2019, 213)

Роза, следствено, савремено, глобализовано друштво - које карактерише брз темпо и краткорочност разних облика развоја, трендова и веза описује као „друштво убрзања“ (Roza 2019, 259). Међутим, на овом месту важно је истаћи и парадокс који произилази из истовеменог постојања првог и трећег вида убрзања. Наиме, било је очекивано да ће техничко убрзање - које се „може дефинисати као намерно повећање брзине циљно усмерених процеса; оно се пре свега односи на техничко и технолошко (дакле, машинско), појачавање темпа којим се могу реализовати транспортни, комуникациони и производни процеси“ (Roza 2019,213) - условити више слободног времена и, заузврат, успорити темпо живота (Wajcman 2015, 16). Чињеница да се догодило обрнуто тј. да је дошло до оскудице времена, довела је до потребе да се нагласи да термин друштво убрзања има смисла употребити искључиво на друштво код којег постоји истовремено технолошко убрзање и растући недостатак времена (Wajcman 2015, 16) што се, нужно, одражава и на темпо живота. „Повећање тема живота (не брзине као такве!) ‘субјективно’ се огледа у процесу осећаја временског притиска, временских ограничења и стресне присиле на убрзање, као и страха од “губљења корака'“ (Roza 2019, 218).

Уколико се прихвати Розина тврдња да је брзина „као доминантна друштвена норма модерних друштава готово потпуно 'натурализована' у друштвеном дискурсу“ као и то да служи за легитимизовање расподеле признања и неуважавања, постаје изразито важно упутити и у начело надметања за које аутор наглашава да је „интринзично повезано с логиком убрзања у појму 'учинка' (као рада по јединици времена“) (Roza 2019, 309310). Динамика (признања) која је створена логиком надметања и учинка, према аутору, представља централни покретачки механизам друштвеног убрзања (Roza 2019, 310). Због тога је, на овом месту, важно нагласити Розину тврдњу да позиција коју неко заузима у модерном свету, па и у мултинационалној компанији, није предодређена него се „(барем начелно) додељује према логици надметања““ (Roza 2019, 311): 
Борба за признање трансформише се из борбе за позицију у борбу за учинак; признање више није резултат тока живота, него такође и у све већој мери одраз свакодневне конкурентске борбе. Данашњи тријумфи и успеси вреде мало или чак више не вреде ништа. Признање и статус стога више нису кумулативне величине, него су непрекидно у опасности да се у кратком временском распону обезвреде сталним протоком догађаја и динамичним променама друштвених мапа. (Roza 2019, 312)

Укратко: док је борба за признање у компетитивном друштву несумњиво суштински покретач друштвеног убрзања, са све већом брзином друштвених промена она мења свој појавни облик на сасвим одлучујући начин. Логика борбе за признање не може се примерено схватити док год ту временску димензију не узмемо довољно у обзир. (Roza 2019, 313)

Као крајње напомене, ваља истаћи и то да Роза запажа да логика друштвеног убрзања и повезане присиле почињу попримати одлике тоталитарне владавине у модерном друштву, али и над њим (Roza 2019, 314). Принудна сила друштвеног убрзања чини да субјекти буду „у сталном страху да неће бити у стању остати у току с ‘клизиштима' живота (која се умножавају интензивирањем диференцијција) и тако задржати своје место; да ће заостати, изгубити прикључак, бити 'отквачени', да више неће моћи одрадити све дуже 'листе задатака' и стога бити искључени из кола рутине, јер су сувише спори или им је потребна пауза“ (Roza 2019, 315). Оно што је, међутим, значајно истаћи јесте то да аутор примећује да тај режим присиле не бива перципиран као друштвено насиље, будући да се време и даље доживљава као природна чињеница због чега се присиле брзине схватају као објективна ограничења, док истовремено субјекти криве „сами себе и своје лоше управљање временом, своју кратковидост и неспособност планирања, своју тромост, спорост или недисциплинованост (Roza 2019, 316) како је већ показано на примеру истраживања из 2005. године (Milosavljević i Dražeta 2021), док ће умногоме важити и за истраживање чији ће резултати бити презентовани у наставку.

\section{Методологија истраживања}

Истраживање је спроведено у оквиру представништва једне мултинационалне компаније у периоду од 2015. до 2016 године, када је интервјуисано педесет шест испитаника уз помоћ структурираног упитника са јасно дефинисаним и једнозначним питањима (Vučinić-Nešković 2013, 140). Коришћени су такође метод опсервације и обављано је посматрање са учествовањем, док је вођење теренског дневника служило као оквир за уписивање битних активности и догађаја на свакодневном нивоу, као и бе- 
лежење садржаја неформалних разговора. Сви запослени су као испитаници попунили и кратку анкету о њиховом демографском и социоекономском профилу, ради потпунијег сагледавања одговора које су давали током интервјуа. Избор оваквог „комбинованог“ истраживачког метода (интервју, анкета, опсервација и посматрање с учествовањем) где је првенство дато квалитативном приступу начињен је због добијања целовите слике феномена који је одабран за проучавање, одноосно анализе грађе која се односи на тему овог рада. У таквом случају, опсервација са различитим степеном учествовања и интервјуима различитих врста служе за добијање одговора у вези са проучаваном темом у главном делу истраживања, док је анкетни упитник заступљен у почетном или завршном делу теренског истраживања (Vučinić-Nešković 2013, 45), са циљем добијања демографских података и података радним позицијама испитаника. Пропагандни материјал компаније у штампаном и електронском облику такође је био један од извора проучавања, ради стицања увида у то какву пожељну слику предузеће жели да прикаже о себи у медијима и јавности. Мултинационална компанија у којој је истраживање спроведено бави се ревизијом, рачуноводством и пружањем саветодавних и сродних (пореских, трансакцијских) услуга у вези са решавањем различитих пословних проблема у другим организацијама. У оквиру представништва компаније са седиштем у Београду запослено је око две стотине особа, док се на светском нивоу помиње цифра од око 300.000 упосленика у већини држава света. Сви испитаници су у периоду од 2015. до 2016. године радили за ову компанију, која у Србији послује од 1997. године. Због анонимности неће бити навођена њихова имена, као и само име фирме у којој је истраживање обављено.

Међу педесет шест интервјуисаних испитаника налази се двадесет шест мушкараца и тридесет жена. Релативна већина упосленика припада средњој генерацији (између 30 и 60 година), док припадници млађе генерације (до 30 година) чине релативну мањину. Испитаници ни у једном случају нису били припадници старије генерације (преко 60 година), а један од руководилаца компаније је у усменом разговору казао да је компанијски просек био између 30 и 35 година у периоду спровођења истраживања од 2015. до 2016. године. Када је реч о радним позицијама у фирми, већина испитаника припада позицијама приправника и асистента, које се односе на упосленике са радним искуством од неколико месеци до три године. Наредне по рангу у оквиру организације, позиције сениора и менаџера (између три и девет година радног искуства), поседује око једне трећине испитаника. Напослетку, најмање испитаника припадало је позицијама сениор менаџера, извршног директора и партнера (преко девет година искуства у фирми), којих такође има најмање судећи према укупом броју запослених. Већина испитаника који се налазе на нижим позицијама (приправник 
и асистент) радила је у сличним ревизорским кућама или им је запослење у овој мултинационалној компанији прво у радној каријери. Мањи број испитаника на вишим позицијама (сениор, менаџер, сениор менаџер, извршни директор и партнер) радио је у другим фирмама, чија је делатност била претежно иста - ревизија и пружање саветодавних и сродних услуга различитим организацијама са различитим пословним потешкоћама. Флуктуација новозапослених је изразито велика, будући да се непрекидно запошљавају нови, претежно млађи људи, док старији морају да се прилагођавају све већој броју нових стратегија пословања, тренинга и других видова обука. ${ }^{5}$

Поједини интервјуи су обављени уз присуство једног од руководилаца у компанији, што је додатно учинило услове под којима је истраживање вршено сложенијим. Неки од њих су касније током неформалних разговора излагали другачија мишљења па чак и понашања у вези са одређеним појавама. Многи су желели да упитник имају код себе пре самог интервјуа, због чега се може рећи да су долазили, условно речено, „спремни“ са одређеним сетом одговора. Иако је у почетку руководилац желео да има увид у то ко ће и када бити интервјуисан, временом је ова пракса код њега потпуно ишчезла, због штога што је један аутор овог чланка почео са обављањем стручне праксе у фирми. То је била уједно и друга отежавајућа околност, односно двојна улога истраживача с једне стране и практиканта у фирми с друге. Критички поглед на оно што се дешавало у организацији био је третиран од стране челника исте као „издајничко понашање“ (Kreeger 2007, 9), у смислу опасности од нарушавања унутрашњег пословног система, чега се прибојавају руководиоци многих компанија. Због тога је истраживачка позиција била уједно и пословна, што је стварало дупло „оптерећење“ не само осмишљавањем тока истраживања, упитника, спровођењем интервјуа, као и посматрањем и бележењем важних активности и догађаја, већ и радним обавезама. Рад под тензијом није дозвољавао непрекидно вођење опсервације али је омогућио учествовање у ономе што је предмет проучавања, тј. стављање у улогу проучаваних. Због свега наведеног, може се рећи да је позиција истраживача-практиканта била јединствена јер је имала „дупли карактер“, како истраживачки тако и радни.

5 Треба напоменути да су аутори чланка дошли до сазнања да се целокупни радни колектив такође прилагодио тренутној ситуацији по питању пандемије Ковида 19, где готово сви упосленици раде од куће, што у великој мери смањује трошкове самог послодавца којима мултинационална компанија пружа своје услуге. Стога сматрамо да су нови правци истраживања у новонасталим условима једна од могућности за даље проучавање феномена везаних за радне колективе, односно организације у српском друштву уопште, као и за флексибилне облике рада.

Етноантрополошки проблеми, н.с. год. 16 св. 2 (2021) 
Истраживање је било под будним оком наведеног руководиоца и неколико других запослених директно подређених њему, што је проучавање чинило изузетно неповољним. Комуникација између групе практиканата којима је истраживач припадао и неколико запослених у истом одељењу, одвијала се тако да је свака похвала или критика на рачун обављања радних задатака практиканата била у већини случајева групна, а у мањој мери појединачна. Обим пословних обавеза је непрекидно успоравао истраживање, највише уговарање интервјуа и спровођење истих, уз отежано бележење свакодневних активности и догађаја, као и садржаја неформалних разговора у теренски дневник. Једна од замерки приликом добијања повратних информација о дотадашњем учинку у фирми била је та што је код истраживача стално постојала једна свеска у коју су уписиване белешке, будући да је сваки појединац требало да буде максимално посвећен раду, а не, како се тада навело „споредним стварима“. Због свега нареченог се може рећи да је истраживач овде практично био „тезгарош“" ${ }^{6}$ што су приметили испитаници који су га због тога доживљавали и као колегу и као, условно речено у већини случајева, „цинкароша“. У мањем броју случајева постојало је разумевање за делатност којом се баве антрополози у компанијама, док је код осталих испитаника већински владала бојазан да се нешто што ће рећи током неформалног разговора и интервјуа погрешно не искористи и тиме директно угрози њихова радна позиција, а понегде чак и егзистенција.

Са наведеним потешкоћама се носе готово сви истраживачи у оквиру корпоративних средина, јер треба да праве равнотежу између осетљивих питања о којима испитаници говоре отвореније пред њима и руководства које тако нешто настоји да сазна. Истраживање у таквим компанијама повлачи низ етичких питања, од плана проучавања до разлиитих препрека и сукоба током обављања теренског рада (Cefkin 2009, 18). Илдико Ердеи сматра да компаније са својим просторима, наративима и праксама представљају „изазов конвенционалном теренском искуству, у коме је уобичајено да се уважава снага јединствене локације и њен одређујући значај за истраживачку ситуацију и самопоимање испитаника“" (Erdei 2014, 358). У случају овог истраживања, упосленици су се више плашили сопственог руководства него јавности, пошто су уочавали одређене негативне карактеристике код својих колега (гордост, егоцентричност, усмереност ка профиту), али су и даље желели да остану на свом радном месту, што их је спречавало да пред истраживачем дају оцене у вези с туђим понашањем и учинком. Ипак, то је био случај током неформалних разговора, али само када истраживач са собом није носио више пута поменуту бележницу.

${ }^{6}$ Онако како су особе са приватним ангажманом у оквиру радног времена, понекад и у оквиру радних просторија, квалификоване у претходном прилогу који је упутио у резултате истраживања из 2005. године (Milosavljević i Dražeta 2021, 94). 


\section{Има ли живота после посла?}

Када је реч о поштовању сатниие, према исказима већине испитаника, уобичајени радни дан у мултинационалној компанији практично није устаљен, већ се сваки разликује по обиму, интензитету и типу посла који треба обавити. Задужења се распоређују на мањим састанцима тимова који треба да обаве одређени посао. Постоје два различита начина обављања радних задатака. Први је везан за одлазак код различитих клијената ван фирме, док је други везан за канцеларију.

Радни дан овако грубо речено, долазак ујутро на посао, ако нема одмах посла увек је ту мало ћаскање са људима пре него што се седне за компјутер, поприча се о дневним темама или нашим интерним стварима и онда се ради до паузе, наравно на неким паузама се попије вода или кафа, пауза за ручак, затим повратак на посао, опет рад, и зависи колико има посла одлазак кући између пет и седам, некад чак и касније. (J.Н.)

Тзв. „флексибилна политика радног времена“ (Flexible policy) коју компанија има подразумева то да запослени на почетку сваке календарске године, у јануару и фебруару, раде десет сати, затим у марту девет, да би тек од априла свако од њих проводио осам сати на радном месту. По том основу касније имају право на неколико нерадних дана. Овде се израз „флексибилна“" користи због тога што свако треба да ради док не заврши свој део задатка на неком пројекту, а количина времена која је за то потребна разликује се од особе до особе. С тим у вези, период од јануара до априла именован је као „сезона“, јер се тада не излази са посла пре осам или девет увече, а понекад остаје и до три ујутро. Многи испитаници су истакли да у том периоду спавају у просеку четири сата дневно због чега на овом месту ваља указати и на забринутост која се јавља у дебатама о балансу између рада и живота, будући да се:

људи покушавају носити са притисцима савременог друштва, проналазећи довољно времена за посао, време за своје породице и доколицу - чак и време за спавање. Заиста, жеља за успоравањем темпа живота све више се појављује у студијама среће и благостања. Недостатак контроле над сопственим временом и неједнак приступ доколици идентификују се као важне димензије социјалне правде (Wajcman 2015, 1).

Неки су се и нашалили ${ }^{7}$ на свој рачун јер су навели да „раде на миру“ у фирми тек након што већина колега оде из ње око 18 часова, што са друге стране може да укаже и на појединачна искуства која се тичу растућег

7 Овакво коришћење шале може бити схваћено и као део личне стратегије запослених да проговоре о одређеним проблемима, као што ће бити могуће показати и на другим примерима у наставку рада. 
осећаја повезаности са другима, па и на културу непосредности, или преовлађујућег доживљаја хитности и, можда, присиле које су у вези са нашим краткорочним преокупацијама (више у: Tomslinson 2007, 74). Међутим, након што се задатак обави, неки од њих не долазе неколико дана на посао јер нема пројеката и нових обавеза које треба обавити. На овај начин изнова се, али на другачији начин, потврђује императив рада до обављеног посла. Дати императив, понајвише мада не искључиво, важи за тзв. нове професије које се примера ради везују за тзв. радни свет нове економије и за високо квалификоване упосленике (више у: Rosa 2013, 168). Међутим, овоме ваља још једном додати и то да притиску нису изложене све друштвене групе на исти начин, али и то да разлике постоје и унутар њих када разлике постоје у оквиру саме радне организације. Конкретно, док запослени у једном одељењу београдског представништва компаније негодују да клијенти код којих одлазе да раде немају обзира према њиховом времену, запослени из другог одељења говоре како могу да планирају време јер пред собом имају годишњи план са наведеним клијентима код којих треба да иду ван фирме, због чега могу да планирају време - чиме се још једном показује да је контрола над временом она која је кључна за разумевање доживљаја убрзања (за примере из истраживања спроведеног 2005. године више у: Milosavljević i Dražeta 2021).

Други пример, међутим, указује на притисак - који ствара утисак убрзања - проистекао из немогућности да се време контролише на више планова истовремено. Код ове врсте притиска интензитети се типично разликују код мушкараца и жена код којих је притисак још и већи ако се ради о запосленим мајкама што је у сагласју и са теоријским поставкама које иду у прилог томе да различите групе људи у модерним друштвима бивају на различите начине изложене датом феномену (више о притиску које осећају запослене жене које су и мајке у: Wajcman 2015, 86; о домаћем примеру више у: Milosavljević i Dražeta 2021, 89). У конкретном случају, улога мајке у оквиру мултинационалне компаније била је под надзором руководства с једне и остатка запослених с друге стране. Истраживањем је детектовано и то да су руководиоци настојали да сваку жену која се врати са породиљског одсуства припреме да обавља радне задатке исто као и остатак радног колектива. Запослени су, пак, у нешто већем броју случајева имали слична очекивања и чак осуде уколико се мајке не прилагоде радним условима у што краћем року.

Даље, будући да уобичајени радни дан у компанији није устаљен, неизвесност са обимом радних обавеза је већа и свакодневни живот је подређен послу. Чести су случајеви када неки радни задатак мора хитно да се обави, на шта су указали сви запослени током неформалних разговора. Наиме, ни њима самима понекад није било јасно шта се од њих тачно тражи и које 
су њихове обавезе на одређеном пројекту. Већина неких ствари остајала је недоречена па су многи прибегавали тактици, како наводе, „снађи се са оним што имаш“. Између овакве праксе и тврдњи запослених да „тимови имају одличну комуникацију између себе“ и да је „све отворено ка томе да сви буду третирани једнако“, ствара се пукотина која се продубљује новим незадовољствима чије испољавање није видљиво на први поглед већ само уколико се о тој теми са испитаницима прича ван формалних интервјуа. Овај пример, као и поједини из истраживања спроведеног 2005. године, када су као разлози за кашњење у раду навођени, управо, тимски рад, туђа грешка и неорганизованост или „објективна“ околност лоше планираног посла и нереални захтеви претпостављених (Milosavljević i Dražeta 2021, 93), иду заправо у правцу демонтаже идеализоване слике тимског рада о којем ће још бити речи у наставку.

Запослени су истакли да су услови за рад на завидном нивоу и да им годе величина и унутрашње уређење радног простора (о односу времена и простора више у: Rosa 2013, 27-29), као и техничка опремљеност (о тзв. друштву високе брзине и дигиталним технологијама више у: Wajcman $2015,37)$ и могућност обедовања на послу. У питању је отворени тип канцеларије, који се још назива и ореn space, пројектован са циљем да се повећа комуникација између запослених. О овоме је више писано на другом месту (Davis, Leach and Clegg 2011, 193-235). У оквиру радног простора запослени имају кухињу и све потребне кухињске апарате, али и библиотеку, собу за одмор у којој је дозвољено пушење и друге просторије које су осмишљење тако да се у оквиру фирме проводи што више слободног времена које, на овај начин, бива заправо оркестрирано и контролисано и, пре, представља дозвољене упливе активности које припадају домену приватног, него слободног времена. Мало опсежнији исказ којим се сагледавају и неки узроци таквог уређења простора, дао је један од запослених.

It's very bright, open space which promotes open communication. When everyone is in the office it's noisy, busy, but because of the nature of our work a lot of the time, depending on what we are doing, we are with clients. We have a lot of, utilization we call it, now as a firm, an office of the future concept, so it means that people don't have any more their desk where they come in, it's common desk, less formal, more relaxing areas. (R.B.)

Компанија своју организациону културу дефинише у односу на низ елемената, састављених од одређених вредности, међу којима се многе односе на лични и професионални развој запослених. Како испитаници наводе, то захтева посебан однос према времену у смислу посвећености ефикасном обављању посла. Другим речима, приватно време је све мање заступљено у корист радног времена. Одлазак са посла после пет часова по подне односно остајање у фирми док се одређени задатак не заврши, постају нешто 
што се третира као „нормално“, за разлику од раније идеје да је „нормално“ радити, управо, од девет до пет (Wajcman 2015, 140). Усавршавања се организују у виду тренинга, радионица, као и приступа глобалним базама знања и информација (више у: Dražeta and Dražeta 2020, 514-515). Те праксе су од стране испитаника оцењене као нешто што мора постојати, будући да су сви прошли кроз неке од видова додатних обука од тренутка када су се запослили.

Људи тако имају прилику да заиста осете да су део једне глобалне компаније, да се сусретну са људима из других земаља, када на једном месту сретнеш преко хиљаду људи свих боја, дезена и вероисповести, осетиш да си стварно део нечег много важног и великог, тако да ја лично рецимо не пропуштам прилику сваке године да одем бар на један тај тренинг, као support, као неко ко ради у организацији јер ми то напуни батерију, просто желим да будем део те приче. (Ш.А.)

Према речима испитаника, за тренинге и остала пословна усавршавања компанија издваја велики део средстава, што износи негде око једну трећину од укупних прихода на годишњем нивоу. Механизам тренинга путем кога се преноси организациона култура једне компаније према запосленима представља средство јачања пожељног понашања у компанији, јер се тако добијају знања која запосленима омогућавају напредовање у сваком смислу (Каmoche 2000, 749). Међутим, различита усавршавања могу бити сагледана и као оне активности које, управо, замагљују границе између рада и живота (Rosa 2013, 172-173) због тога што остају, практично, 'приватно власништво' онога ко је кроз дате процесе прошао, тиме му дајући већ наглашену прилику да напредује у оквиру колектива који улаже у кадрове, али и да мења колектив у оквиру личне стратегије изналажења боље радне перспективе. Даље и конкретније, поред тога што могу да обухватају обуку техничке природе, тренинзи нуде управо те „процедуре учења повезане са успостављањем односа са клијентима“. Тако запослени могу да примењују високе професионалне стандарде у свом раду (Vučinić-Nešković 2011, 97). Исти је случај и са свим другим облицима издвајања времена запослених зарад радног „вишег циља“. Међутим, током неформалних разговора многи су указивали да су усавршавања, како наводе, „потпуно бесмислена“ јер одузимају пуно времена и појединац не може много да научи. Штавише, неки су улазили у отворене сукобе са колегама у оквиру исте организационе јединице, због тога што нису желели да учествују у бесконачном оцењивању учинка запослених. Разлог је био због тога што су морали да попуњавају много образаца, формулара и других облика „папирологије“, да би саопштили нешто што могу да искажу у неколико реченица. У овом случају, време им је било како и сами кажу „драгоцено“, наглашавајући да су га ,уззалуд потрошили на бирократију и остале глупости“. 
Када је требало да буду интервјуисани, запослени су говорили да немају времена зато што много раде. Многи од њих су били сумњичави према истраживању, настојећи да у шали назову истраживача „шпијуном“који ради за „стране службе“. Дешавало се да интервју желе да обаве након што би чули од колега да је све прошло како треба, мада се радило о инату којим су желели да покажу да своје време могу да организују тако да уз радне задатке успешно завршавају и додатне активности. Поред тога што им је време било битно, многи нису желели да дају интервју јер би у том случају били у страху за своје радно место, што су истицали у ћаскању ван фирме (о страху повезаном са губљењем радног места и угрожености услед растуће незапослености на примеру запослених Београђана који су учествовали у истраживању 2005. године више у: Milosavljević i Dražeta 2021, 82). Зато је код једног броја запослених постојала идеална слика о радном месту током интервјуа, док је ван снимања разговора била другачија, на тренутке чак изразито негативна.

Пример путем кога се може уочити још један однос запослених према времену је прослављање празника, а нарочито породичне славе која „се сматра једним од битнијих обележија српског народа“" (Sinani 2012, 175). Многи испитаници су узимали додатни нерадни дан од годишњег одмора како би прославили славу. Међутим, појединци су неким колегама замерали што узимају слободан дан, а чак су их оптуживали да „измишљају славе“ што упућује на изразиту нетолеранцију „присуства“ приватног у домену пословног на начин да се из приватних разлога одсуствује са посла. Међутим, док су током интервјуа истицали једно, испитаници су у пракси радили друго. Многи од њих су имали осећај да без њих посао неће моћи да се заврши, због чега су радили на дан славе или би имали страх по питању истраге које је руководство планирало да спроведе поводом наводног измишљања слава, ради узимања слободног дана. То је код самог истраживача произвело исти осећај када је обележавао своју славу, јер је узео један слободан дан. Све се то дешавало након месец дана од првог радног дана када је ангажован, што показује колико је појам времена уткан свим новозапосленима као битан фактор у обављању раних обавеза. Један део испитаника је истакао да осим једног дана који им по закону припада, ${ }^{8}$ узима још један или више дана од годишњег одмора како би све припремили ваљано. С друге стране, они који узимају један законски дан настоје да само тада помогну родитељима или укућанима око свих горенаведених

8 Према Закону о државним и другим празницима у Републици Србији (Члан 4.) „запослени имају право да не раде у дане следећих верских празника, и то: 1) православци - на први дан крсне славе“. Католици и припадници других хришћанских верских заједница, као и припадници исламске и јеврејске заједнице такође имају право на један нерадан дан у односу на своје верске празнике (Zakon 2011).

Етноантрополошки проблеми, н.с. год. 16 св. 2 (2021) 
радњи. Били је и оних који су говорили да би своје „уставно право искористили“ иако не славе славу и да не треба „фирма да се меша“ у то да ли они заиста славе или не.

Због свега наведеног, на овом месту ваља указати на то да средства алокације темпоралних ресурса увек зависе од разматрања три нивоа који се тичу времена које неко проводи у професионалном раду, са породицом и у доколици, док физичко благостање зависи од дневне рутине, погледа на живот и процене онога што иде ,у корак са временом“ (или од захтева које намећу време и будућност) (Rosa 2013, 9). Чини се, међутим, да захтеви нису синхронизовани, иако је преплитање пословног и приватног у модерном друштву неодвојиво и неизбежно.

Прослава Нове године, с друге стране, била је дозвољена и пожељна пракса, али у режији компаније. На тој свечаности присуствовали су скоро сви запослени, а термин је био готово три седмице пре календарске Нове године, у ноћи између петка и суботе. Разлог за то је било очекивање да запослени после „бурне ноћи“ неће моћи сутра ујутро да дођу на посао. И заиста, те вечери су многи испитаници које су до јуче били интервјуисани у оквиру компаније као озбиљни појединци показали потпуно супротно понашање, због чега су чак били ангажовани патронажни доктор и медицинска сестра који су читав догађај само гледали са чуђењем. На основу посматрања са учествовањем је закључено да је једна од основних функција новогодишње прославе била да се запослени „опусте“ како би могли да забораве на прекомерне радне обавезе и на недостатак времена за друге активности, али и да пружи врсту супститута друштвеном животу који, парадоксално, не припада сфери рада док се, у конкреном случају, одвија у пословном миљеу. Лични пример показао је то да је приватни живот током обављања стручне праксе био драстично умањен у смислу контакта са породицом и виђања са пријатељима, док је било који од догађаја који је фирма организовала био прихваћен са радошћу, пошто су се догађали изван радног места.

Што се тиче односа запослених према времену у контексту процеса $u$ периода прилагођавања иностраним колегама, одговори и праксе саговорника показују да су у великој мери опредељени да обављају радне задатке као колеге из иностранства. То је у вези са новим концептом флексибилне каријере без граница, где је нагласак на поменутом личном и професионалном развоју појединца ради обављања различитих радних задатака, насупрот традиционалној каријери у којој појединац линеарно напредује у једној организацији спрам доступних позиција (Rifkin 2005). Већина испитаника се запослила у фирми путем стручне праксе коју је обављала у периоду од два до шест месеци, док је већ на својим факултетима где се школовала имала увид у то на који начин се, како наводе „послује у са- 
временом свету“, а како „код нас“. Због тога се може рећи да су у фирму дошли спремни да раде много у временском смислу, како би напредовали у служби. Када су упитани да ли је народ у Србији - барем када је реч о јавном дискурсу или у медијима често коришћеном наративу - неодговоран у смислу да пробија задате рокове, а потом тражи оправдања за све то, испитаници су истакли своје већинско неслагање са овим наводом јер мисле да то није случај и да се таква особина не може приписивати читавом народу већ само појединцима. Међутим, мишљења су да такви људи не би ни опстали у компанији дуже јер је она тако конципирана да рокови јесу суштина пословања, те да појединац који то не поштује може слободно да „напусти радно место“.

Избегавам да генерализујем па нећу да кажем да је у већини неодговоран, наравно да има таквих случајева, негде мање негде више али у компанији ми радимо посао у коме се клијенту обавежемо да ћемо у одређеном року да завршимо тај посао и кад се пробије рок треба утврдити одговорност. (Д.Р.)

Занимљиво је да један испитаник подвлачи дистинкцију између „северњачких народа у Холандији, Енглеској и Немачкој“ и ,,јужњачких народа у Италији, Шпанији и Србији“. Први ће увек долазити тачно на време на састанак у 15 часова, чак понекад и пет минута раније. Други ће долазити на време у најбољем односно петнаест минута касније у најгорем случају. Међутим, компанија за коју раде настоји да им утка поштовање сатнице, насупрот људима који имају „превелика очекивања која се не испуне“. Насупрот томе, други део испитаника рекао је да су људи у Србији недисциплиновани и непромишљени, док неодговорност везују за „прихватање западних вредности у новије време“ (о сличним идејама вуше у: Milosavljević i Dražeta 2021, 91). Уколико касне на посао, запослени не морају да остану на послу зато што морају, већ зато што желе, будући да им је усађен лични осећај одговорности, што су и сами тврдили током интерјвуа. Такође, неки су истицали да обично остају и дуже од онога колико су закаснили, како би могли да заврше одређени посао.

Готово све вредности и елементи организационе културе проучаване мултинационалне компаније садрже концепт времена. Испорука услуге према клијенту у задатом року се стога схвата као лична одговорност, не само колективна. Сатнице се поштују и обраћа се пажња на планирање, што је карактеристично за модерне, рационалне организације (Реšić 2011, 48-49), али и за претходеће фазе капитализма када часовник постаје кључна машина (Mumford 1934, 14). Пут којим запослени у компанији иду замишља се као узлазна линија у оквиру које они могу да напредују и доприносе заједници у којој живе, мада може бити схваћен и као континуирани след покушаја да истрче узастопне трке са временом и тако се одрже на 
послу тј. избегну склизнуће у заостајање и назадовање до губитка радног места. Њихове перцепције, иако разнолике, говоре о култури чије основе почивају на посвећености извршењу радних задатака. Такво уређење настоји да обликује појединце који ће у складу са циљевима компаније да доприносе њеном бољем имиџу на глобалном и локалном тржишту. На основу тога се уочава да је органзациона култура овде замишљена као оруђе, нешто што се може „мењати“ у складу са пословним критеријумима.

Антрополошка критика оваквог концепта иде ка томе да културу више види као процес непрекидног прожимања свих елемената, него као скуп карактеристика. Коришћење кованица као што су „системи значења“ или пак „заједничка веровања и вредности“, имају за циљ да код запослених створе осећај да они заиста раде нешто што је исправно и корисно. Одабир појединаца који почиње са процесом регрутовања (енг. recruitment) има за циљ да окупи оне који су потенцијално заинтересовани да виде како изгледа корпоративни свет. Затим, серије радионица, тестова и разговора за посао сужавају број кандидата који ће бити одабрани да раде у компанији. На крају, процес енкултурације у нову средину одвија се путем поменутих редовних пословних усавршавања и пропагандних материјала које новозапослени добијају, а добија чвршћу ноту практиковањем ритуала. Временом, перцепција организационе културе запослених почиње да подсећа на концепт идиокултуре, тј. културе малих група чији су чланови упућени једни на друге у одређеном временском и просторном контексту и који имају заједничке вредности (Antonijević 2010, 36-37).

У компанији се запослени прилагођавају „иностраним“ концептима пословања, док руководство на основу различитих искустава широм света сматра да је управо таква пословна стратегија веровања свих радника у исти циљ довела до позиционирања ове фирме међу четири најбоље у делатности коју обавља. Запослени свесно схватају да су део овог тима који жели да буде врхунски у ономе што ради али често несвено многи од њих заборављају да проводе велики део свог времена на послу. Чак и ако не раде у самој канцеларији, они могу своје радне задатке обављати на терену или од куће. Битно је увек да се пројекат заврши и да клијент буде задовољан. Долажење до тог циља омогућено је структуралним условима компаније где нико не осећа постојање формалног ауторитета и заиста бива уверен у то да ради оно што је исправно за себе и друге, односно да се усавршава на личном и професионалном плану. Ово је заправо оно што Арли Расел Хочшилд назива емоциналним радом, што подразумева руковођење ума и осећања запосленог ради испољавања пожељене слике коју послодавац тражи. Онај који ради бива отуђен од себе како би посао био обављен (Russell Hochschild 2003, 7), за шта је погодно споменути исказ испитаника који себе види „као мали шрафић у машинерији која ради нешто исправно“. 
Будући да већину времена проводе у канцеларији или на терену, њихово поимање посла заиста почиње да бива у складу са прокламованим вредностима саме компаније, а уочавање и анализа тих процеса је оно што може да представља кључни антрополошки допринос оваквом типу истраживања. Механизми помоћу којих њихова мишљења и ставови постају умногоме исти по питању посла су веома суптилни и припадају домену меке (индиректне) моћи која почива на привлачности нечијих идеја у смислу тога да „други желе оно што и ви желите“. С тим у вези, способност да се установе наклоности према нечему „тежи да буде удружена са нематеријалним ресурсима моћи, као што је култура, идеологија и институције“ (Nedeljković $2011,50)$. Руководство компаније настоји да промовише неформалну атмосферу у којој свако може да се обрати неком другом када му затреба помоћ и на тај начин доприноси осећају заједнице од поверења. Уместо да се организација поима као ограничени простор изолован од спољне средине, може се схватити као место где се нешто непрекидно организује (Pondy and Mitroff 1979, 3-39). Управо такво непрекидно организовање и преговарање означавају процес културе којим се манипулише значењима и основним вредностима (Wright 2005, 20). Зато запослени у овој компанији који раде више него што је прописано остварују The extra mile, чиме своје приватно време губе у корист пословног, у коме се радни циљеви доживљавају као „виши циљеви“.

Неколико испитаника изразило је став да поједини запослени „замењују фирму за породицу“, те да „у њој виде другу кућу“, што је последица њиховог „неизграђеног животног идентитета“, „незрелости“, зато што „немају свој живот, немају ништа ван посла, и немају где да потроше време“ итд. Чак је и један испитаник навео да је преплитање пословног и приватног живота такво „да ту више нема разлике“ и да је однос који неко има према породици и приватном животу такав да се преноси на радно место и колеге па онда посао многи посматрају као „малу породицу“. Дистинкција приватно-јавно на којој је почивала друштвена организација и подела улога још од постанка модерног друштва у XVIII веку уклапала се у оквире свеопштег раздвајања свега у једном систему, од институција, преко друштвених односа до пракси (Ivanović 2010, 22). Данас се не може рећи да је ово случај, јер се приватна сфера заправо све више не може подвојити од јавне која обухвата сваки домен нечије „приватности“. Две сфере живота готово да постају једна, иако људи вербално и даље раздвајају обе, јер им се „посао не меша у живот“ или се код њих „зна шта је шта“ и сл. Прихватање компаније за „другу породицу“, као и читаве радне средине, чини да у њиховим исказима време представља битан концепт не само током посла него и у свакодневном животу. Приватно време готово да престаје да постоји у корист пословног, а о чему сведоче горепоменути наводи у вези 
са доживљајем компаније као породичне средине. Чак и они који то наводе критикујући колеге имају готово исте навике, што је утврђено приликом опсервације свакодневних активности и пракси у канцеларији компаније, а што не би било могуће уочити само на основу исказа.

Даље, када је било речи о томе колико је ко упоран тј. колико времена издваја уколико хоће да изврши задатке које му је фирма поверила, већи део испитаника је навео да то јесте особина читавог радног колектива у представништву компаније у Србији, али и да се у јавном дискурсу или у медијима често користи наратив по коме је народ у Србији упоран.

Ја мислим да је упорност нешто што је стварно код нас својствено и да то стварно помаже запосленима да обаве своје задатке и да буду ту и да раде, ко нема ту упорност оде, нема шансе да опстане, мислим да су Срби генерално упорни као народ. (J.К.)

Запослени су истицали такође да овакво стање ствари „годи компанији“ зато што „сви воле људе који завршавају све што им се каже“. Неки су чак били мишљења да компанија „користи ову особину нашег народа и преусмерава је у другом правцу“ како би на тај начин устројила појединце и избегла евенутално бунтовништво услед било каквог незадовољства. Други, мањи део испитаника сматра да је упорност као карактеристика ишчезла код људи у Србији, почев од 2000. године, и то због „примања западних вредности“" након политичког и економског преображаја српског друштва (о аспектима важним за разумевање дате перпсективе више у: Milosavljević i Dražeta 2021).

У вези са односом запослених према времену пре и након искуства рада са иностраним колегама јесте једна од димензија културе холандског социјалног психолога Герта Хофштедеа. То је дугорочна насупрот краткорочној оријентацији (енг. long-term versus short-term orientation, LTO). Дугорочна оријентација се односи на „неговање врлина оријентисаних ка будућим наградама - посебно упорности и штедљивости. Њен супротни пол, краткорочна оријентација, односи се на неговање врлина које се односе на прошлост и садашњост - посебно, поштовање традиција, очување 'образа' и испуњавање друштвених обавеза“. Србија по питању овог аспекта има „половични“ резултат на скали од 1-100. Са скором од 52 спада у оне земље чији су становници половично плански и стратегијски расположени спрам ситуације у којој се налазе (Hofstede, Hofestede and Minkov 2010, 235-259). Одговори испитаника су углавном били амбивалентни, што је „ишло на руку“ ономе што теоријски модел попут наведеног налаже. Весна Вучинић-Нешковић је истражујући искуства и ставове српских стручњака који су се вратили у земљу након петооктобарских промена, установила да је њихов општи став био да људи са запада, наши привредници 
и бизнисмени треба да усвоје „способност изградње стратегије засноване на дугорочном интересу“, уз професионализам и радну етику, као оно што чини темељ таквог планирања. Циљ таквог истраживања био је показати колики је „културни шок“ који су повратници из иностранства имали након повратка у вези са пословним праксама „тамо“ и „овде“ (Vučinić-Nešković 2003, 279-280). У компанији је истраживач за време радне праксе уочио истоветну тенденцију, према којој се појединци „уче“ да размишљају и делују у складу са нечим што ће временски на „дуге стазе“ донети бољитак првенствено компанији и заједници у којој живе. Супротно овоме, поједини запослени користе народне пословице да опишу шта дугорочност може изазвати, нпр. „човек планира, Бог се смеје“.

Испитаници из Уједињеног Краљевства и Швајцарске имали су готово истоветна односно половична размишљања као и њихове српске колеге, што се поклапа са британским резултатом (51) али не и швајцарским (74) (Hofstede, Hofestede and Minkov 2010, 255-256). За испитаника из Уједињеног Краљевства традиција свакако има „одређено место у животу“ али човек и људи се морају прилагодити времену у коме живе. По његовом мишљењу, „сви треба да имају циљеве којима теже, али исто тако морају знати да не може сваки од њих бити остварен онако како је замишљено на почетку планирања““. Испитаник из Швајцарске определио се строго за „прилагођавање околностима због тога што се и свет мења“, али је по питању циљева рекао да није особа која ће „убити да би победила“, те да „сваки циљ мора бити друштвено прихватљив“. Запослени из српске средине претежно сматрају да је питање у коме треба да се определе између традиције и прилагођавања околностима „противречно“, јер ,једно увек може ићи са другим“. Парадокс Хофштедовог упитника био је на делу, јер половини испитаника није било јасно „шта је ту чудно што поштујеш традицију и живиш спрам времена и околности који те окружују“. Друга половина испитаника „определила се“ за прилагођавање околностима, зато што им традиција „није јача страна“, или јер „у фирми нема неких традиционалних вредности“. Поред тога, сви до једног истакли су да никада не би никога „згазили“, „преварили“, „убили“, „зезнули“ да би дошли до циља јер „мора да се зна ко докле може да иде“.

Ја сам мало више за традицију али и прилагођавање, да се поштује традиција али да се гледа спрам времена. Јесам усмерена ка циљу али постоје ствари преко којих не би прешла, значи не оно газим преко свега да би стигла до циља. (К.Т.)

Један испитаник рекао је да ће традиције да се држи у будућности када буде мало напредовао на послу, јер за сада то није могуће зато што „нема времена“ пошто „ради за плату“, па се томе тренутно прилагођава. Про- 
слављање породичне славе служило је као пример када су испитаници требали да изаберу између празновања овог обичаја или рада у компанији, о чему је детаљније писано у претходном делу овог чланка.

Препуштање насупрот уздржавању (енг. indulgence versus restraint, IVR) је димензија у којој препуштање означава „тенденцију да се омогући релативно слободно задовољење основних и природних људских жеља повезаних са уживањем у животу и забавом. Супротно овоме, уздржавање одражава уверење да такво задовољење треба обуздати и регулисати друштвеним нормама“. Друштва склона препуштању имају „висок проценат јако срећних људи“ који сматрају да имају контролу над својим животом и придају важност слободном времену (разоноди, доколици). Поред тога, чланови друштва имају „мање моралне дисциплине“, ,„озитиван став“, „висок проценат људи који се осећају здраво“ итд. Све што важи за друштва склона уздржавању је супротно наведеним карактеристикама, при чему је таква и Србија која има резултат од 28 (Hofstede, Hofestede and Minkov 2010, 280-291).

Што се тиче запослених из Уједињеног Краљевства односно Швајцарске, слободно време је веома битно у њиховом свакодневном животу и проводе га у рекреацији или са породицом. Сматрају да не могу контролисати све у свом животу нити томе желе да теже јер се сваки човек треба, како наводе, „прилагодити околностима које му се дешавају“. Резултати Уједињеног Краљевства и Швајцарске врло су блиски - 69 и 66 (Hofstede, Hofstede and Minkov 2010, 282). То их ставља у ред оних култура које немају строго одређене норме понашања својих чланова, те им на тај начин пружају да својим слободним временом располажу онако како они желе, а да притом за ствари које им се дешавају не могу да криве некога из своје непосредне околине (лидера, судбину, државу).

Код свих испитаника из Србије присутан је одсечан став да се мора знати ред, подела улога и шта се од кога очекује на радном месту, јер у супротном настаје „расуло, анархија, безвлашће, а то не води ничему добром“. У том смислу изјаве попут тога да је хијерархија добра зато што „помаже свима“" или да „треба да се зна се ко пије а ко воду носи“, биле су карактеристичне за њихове ставове и размишљања по овом питању. Што се тиче слободног времена, мишљења су подвојена. Док једна страна сматра да је одмор веома важан аспект живота пошто омогућава човеку да „напуни батерије“ или „ради нешто што иначе не може“, друга, већинска страна у ствари и нема изражен одмор у том смислу јер посао ни тада не изостаје у њиховом животу. Неколико њих је изјавило да личне лап топ рачунаре носи са собом на летовање али само да би проверили да ли се нешто ново десило у фирми. Како и сами кажу, ,увек има неких хитних ситуација, увек има неких проблема који морају да се реше“. С тим у вези, испитаници су 
говорили да слободно време проводе радећи или су се смејали говорећи да у ствари немају слободно време или да га у последњих неколико година „имају све мање“, јер им не прође ниједан одмор а да не размишљају о послу. Сматрају да је то у ствари „вероватно субјективни осећај да ће се све урушити“ ако напусте фирму на две недеље због личног осећаја одговорности, али и осећаја угрожености и страха од временског и сваког другог назадовања, мада знају да се то заправо неће догодити. Њихове колеге које своје слободно време не проводе радно се одмарају, читају књиге, баве се различитим врстама спорта, друже са породицом и пријатељима, проводе време у природи или у граду на разним местима, а неки чак гледају у једну тачку да би одморили очи од рачунара испред кога проводе већи део дана.

Свакако треба да се зна ред у компанији. Углавном слободно време проводим бавећи се спортом, кошарком, проводим време са друштвом, породицом, пријатељима итд. За сад сам, што кажу за сад сам са̂м свој газда, здрав сам прав сам и још увек могу да размишљам и доносим одлуке које желим али опет не могу на све да утичем. (К.Ђ.)

Дакле, оно што се може рећи за већину запослених у мултинационалној компанији је да прихватају и сматрају хијерархију нужном у било каквој радној организацији и своје слободно време практично проводе у активностима везаним за сам посао чиме слободно време престаје да то и буде. Многи приписују одређене активности и догађаје из свог живота „спољашњем фактору“, верујући да не могу имати контролу над оним што им се дешава. Међутим, мањи део запослених слободно време користи у потпуности путем разних садржаја, трудећи се да своју породицу и пријатеље не оптерећују проблемима са посла. Један још мањи део сматра да може да контролише свој живот у потпуности, јер нико други осим њих није одговоран за то.

\section{Завршна разматрања}

За разлику од претходног прилога у коме је показано да се код запослених Београђана различитих пословних оријентација границе између пословног и приваног живота замагљују услед друштвеног убрзања у оквиру српског друштва на прелазу векова (Milosavljević i Dražeta 2021), у овом прилогу се може констатовати да је, даље убрзање довело до тога да је пословни живот готово већински обухватио приватни када је реч о упосленицима у мултинационалној компанији. То се очитава кроз радно време које код већине испитаника практично престаје да има јасно одређене темпоралне међе, већ се у оквиру истог обављање радних задатака одвија у контексту спајања пословне и приватне сфере живота у једну. Анализирање 
грађе извршено је на три нивоа: поштовање сатнице, процес и период прилагођавања иностраним колегама и однос запослених према времену пре и након искуства рада са иностраним колегама. Наведени нивои имали су за циљ да у једној одређеној организацији на микро нивоу пруже увид у дешавања на макро нивоу (државе), углавном везана за европеизацију српског друштва, нове концепте пословања (отварање представништва различитих мултинационалних компанија) и поимања времена усмереног све више ка профиту и друге реформе у политичко-правном поретку земље.

Друштвено убрзање током друге деценије XXI века на примеру запослених у представништву једне мултинационалне компаније у Београду показало је да је доживљај радног времена и карактеристичних темпоралних међа које га одређују код упосленика такав да је приватно време готово у потпуности узурпирано временом проведеним у раду. Горепоменута три нивоа, помоћу којих је анализиран процес убрзања времена, издвојена су на основу исказа саговорника послуживши као поредбени оквир са претходним истраживањем рађеним 2005. године, у коме је преиспитивање истог феномена показало да је постепено брисање граница између сфере пословног и приватног код запослених Београђана било све израженије у оквиру неколико аспеката, а у контексту пре и током реформских промена започетих након 2000. године (Milosavljević i Dražeta 2021, 75-76, 98-100). Потицаји уоченог убрзања су у овом истраживању јасно видљиви кроз поштовање сатнице - радно време више није стриктно одређено већ га диктира обим, интензитет и тип посла, за чије обављање су заслужни, између осталог, величина и изглед радног простора, наменски пројектовани да се у њима проводи што више времена. Редовна пословна усавршавања су нешто што у том смислу делује као амбивалентна појава, с једне стране погодна као део приватног времена које се користи за напредовање у оквиру пословне хијерархије, а с друге стране непотребан бирократски аспект који радно време отеже и продужава. У складу са тим се даље организују обележавање празника (крсна слава, Нова година) који, дакле, и поред тога што припадају домену приватног живота, јесу под снажним утицајем пословне, радне сфере. Добровољност појединаца, са друге стране, одражава намеру па и присилу да се одрже $y$ времену тј. у послу. Процес и период прилагођавања иностраним колегама нам показује да упосленици углавном стреме обављању радних задатака попут колега из других земаља, у овом случају Уједињеног Краљевства и Швајцарске, мада и других делова света, будући да је фирма веома распрострањена на глобалном нивоу. Суштина пословања јесте у испуњавању разноразних рокова и јаком осећају одговорности, рада у служби „вишег циља“, чему доприноси организациона култура компаније, конципирана тако да прокламује време као фактор ефикасног обављања посла. Процес енкултурације новозапослених у овакво радно окружење мултинационалне компаније врши се помоћу 
тачно утврђеног линеарног процеса (регрутовање, селекција, редовна пословна усавршавања, ритуали), а што даље утиче на то да приватно време практично престаје да заузима одређени део свакодневног живота, јер је све подређено радном времену, макар декларативно, при чему се радна средина чак доживљава као породична. Напослетку, однос запослених према времену пре и након искуства рада са иностраним колегама показује да је убрзање претежно довело до њихове организације времена у односу на циљеве компаније, те да се поред поштовања одређене традиције треба прилагођавати све бржем темпу у коме се живи који, заправо, подразумева већи број обавеза и истовремено деловање и на пословном и на приватном плану. Општа оцена је да код домаћих упосленика долази до скраћивања тзв. слободног времена - времена намењеног доколици и одмору - у корист радног, при чему је код странаца заступљен став да треба очувати равнотежу између две наведене сфере живота. Управо је код тих странаца приметно, условно реченено, растерећење по питању равнотеже између приватног и радног времена које би се могло објаснити тиме да иако потичу из центра, тренутно делују на периферији глобалног капиталистичког мултинационалног система што, свакако, јесте занимљива тема за будућа истраживања и разраде. Испитаници из Србије се залажу за постојање строго одређене хијерархије, где су активности и догађаји детерминисани „спољашњим фактором“ на који они као појединци не могу да утичу док истовремено испољавају и отпоре на више планова, што је показано и налазима из претходног истраживања, мада у знатној мери измењеним социоекономским околностима, па и у погледу датог радног процеса.

\section{Литература}

Antonijević, Dragana. 1986. „Ritual puštanja montažne trake u pogon u proizvodnji "Juga 55 GV". Etnološke sveske 7: 39-46.

Antonijević, Dragana. 2009. „Okviri proučavanja ličnih i porodičnih priča o materijalnom gubitku i porazu“. Etnoantropološki problemi 4 (1): 13-35. https://doi. org/10.21301/eap.v4i1.1.

Antonijević, Dragana. 2010. Ogledi iz antropologije i semiotike folklora. Beograd: Srpski genealoški centar - Odeljenje za etnologiju i antropologiju Filozofskog fakuteta, Etnološka biblioteka 51 .

Baba, Marietta L. 2006. "Anthropology and Business". In Encyclopedia of Anthropology, edited by H. James Birx, 83-117. Thousand Oaks: Sage Publications.

Baba, Marietta L. 2012. "Anthropology and Business: Influence and Interests". Journal of Business Anthropology 1 (1) (Spring): 20-71. https://doi.org/10.22439/jba. v1i1.3546.

Bate, S. P. 1997. "Whatever Happened to Organizational Anthropology? A Review of the Field of Organizational Ethnography and Anthropological Studies". Human Relations 50 (9): 1147-1175. https://doi.org/10.1177/001872679705000905. 
Batteau, Allen W. and Carolyn E. Psenka. 2012. "Horizons of Business Anthropology in a World of Flexible Accumulation”. Journal of Business Anthropology 1 (1): 72-90. https://doi.org/10.22439/jba.v1i1.3547.

Bolčić, Silvano. 2002. „Izmenjena sfera rada“. U Društvene promene i svakodnevni život: Srbija početkom devedesetih, uredio Silvano Bolčić, 79-108. Beogad: Institut za sociološka istraživanja Filozofskog fakulteta u Beogradu.

Bratić, Dobrila. 1984. „Ceremonija ispraćanja radnika u penziju“. Etnološke sveske 5: 99-104.

Caulkins, D. Douglas, and Ann T. Jordan. 2013. "Expanding the Field of Organizational Anthropology for the Twenty-first Century". In A Companion to Organizational Anthropology, edited by D. Douglas Caulkins, and Ann T. Jordan, 1-23. Oxford: Willey-Blackwell.

Cefkin, Mellisa. 2009. Business, Anthropology, and the Growth of Corporate Ethnography, Introduction to Ethnography and the Corporate Encounter: Reflections on Research in and of Corporation, ed. Mellisa Cefkin, 1-37. New York and Oxford: Berghahn Book.

Davis, Matthew. C., Desmond J. Leach, and Chriss W. Clegg. 2011. "The Physical Environment of the Office: Contemporary and Emerging Issues". International Review of Industrial and Organizational Psychology Vol. 26: 193-235. https://doi. org/10.1002/9781119992592.ch6.

Dražeta, Bogdan and Lazar Dražeta. 2020. "Organizational Culture in Ernst Young Serbia: From Proclaimed to Perceived Values”. Etnoantropološki problemi 15 (2): 507-521. https://doi.org/10.21301/eap.v15i2.7.

Erdei, Ildiko. 2009. "Hopes and Visions - Business, Culture and Capacity for Imagining Local Future in Southeast Serbia". Etnoantropološki problemi 4 (3): 81-102. https:// doi.org/10.21301/eap.v4i3.5.

Erdei, Ildiko. 2011. "What's in a Beer? Cultures that Interact in Brewery Privatization". Etnoantropološki problemi 6 (1): 57-85. https://doi.org/10.21301/eap.v6i1.2.

Erdei, Ildiko. 2014. „Stepeni tuge: ekonomska devastacija i društveni zaborav“. Etnoantropološki problemi 9 (2): 351-369. https://doi.org/10.21301/eap.v9i2.5.

Gossiaux, Jean-François. 1992. "Ethnologie et pouvoirs le défi de l'independence". Glasnik Etnografskog instituta SANU 41: 213-220.

Gray, Paula. 2009. "Buisness Anthropology and the Culture of Product Managers". The Association of International Product Marketing and Management. January 12, 2020. https://productmanagement.buzz/index.php/2010/08/08/business_anthro/.

Guang, Tian and Davis K. Tian 2014. "Why is Business Anthropology Important?” Anthropologist 18 (1): 1-5.

Harvey, David. 2005. A Brief History of Neoliberalism. Oxford and New York: Oxford University Press.

Hofstede, Geert, Gert Jan Hofstede, and Michael Minkov. 2010. Cultures and Organizations: Software of the Mind. New York: McGraw-Hill.

Ivanović, Zorica. 2010. „Da li su postojala “na srodstvu zasnovana društva”? O (de)konstrukciji jednog antropološkog koncepta“. Etnoantropološki problemi 5 (3): 19-42. https://doi.org/10.21301/eap.v5i3.1. 
Janićijević, Nebojša. 1997. Organizaciona kultura: Kolektivni um preduzeća. Beograd i Novi Sad: Ulixes i Ekonomski fakultet Univerziteta u Beogradu.

Janićijević, Nebojša. 2013. Organizaciona kultura i menadžment. Beograd: Centar za izdavačku delatnost Ekonomskog fakulteta u Beogradu.

Kamoche, Ken. 2000. "Developing Managers: The Functional, the Symbolic, the Sacred and the Profane". Organization Studies 21 (4): 747-774. https://doi.org/10.1177\%2F0170840600214004.

Kearney, Michael. 1995. "The Local and the Global: The Anthropology of Globalization and Transnationalism". Annual Review of Anthropology 24: 547-565. https://doi. org/10.1146/annurev.an.24.100195.002555.

Kovačević Ivan i Dragana Antonijević. 2014. „Novi rituali i nova srpska antropologija - proces međusobnog konstituisanja“. Etnoantropološki problemi 9 (2): 417-434. https://doi.org/10.21301/eap.v9i2.8.

Kreeger, Lisa Dell. 2007. "Inside Outsourcing: A Grounded Theory of Relationship Formation Within a Nascent Service System.” PhD diss., Antioch University.

Krstić, Saša, Aleksandra Fedajev i Radmilo Nikolić. 2017. "Some Aspects of Business Operations of Serbian Economy in 2017'. Industrija 46 (4): 185-206. https://doi. org/10.5937/industrija46-19735.

Lewis, David. 1999. "Revealing, widening, deepening?: a review of the existing and potential contribution of anthropological approaches to 'third sector' research". Human Organization 58 (1): 73-81.

Lloyd, Andreas. 2008. "Anthropology of business". Andreas Lloyd's Blog. March 8, 2021. http://andreaslloyd.dk/2008/04/anthropology-of-business/.

Malešević, Miroslava. 1984. „Prijem u pionirsku organizaciju“. Etnološke sveske 5: 73-82.

Milosavljević, Ljubica i Bogdan Dražeta. 2021. „Radno vreme kao mera ubrzanja srpskog društva na prelazu vekova: antropološka analiza“. Etnoantropološki problemi 16 (1): 73-104. https://doi.org/10.21301/eap.v16i1.3.

Miokov, Vladimir Ž. 2008. „Antropološka analiza poslovne kulture u Srbiji - Menadžeri u socijalističkom i postsocijalističkom periodu." Magistarska teza, Filozofski fakultet u Beogradu.

Moeran, Brian and Christina Garsten. 2012. "What's in a Name? Editors' Introduction to the Jorunal of Business Anthropology". Journal of Business Anthropology 1 (1): 1-19. https://doi.org/10.22439/jba.v1i1.3545.

Mojić, Dušan. 2010. Kultura i organizacije - Uticaj kulturnih pretpostavki, verovanja $i$ vrednosti na organizacione strukture, sisteme i procese. Beograd: Čigoja štampa Institut za sociološka istraživanja Filozofskog fakulteta.

Mumford, Lewis. 1934. Technics and Civilization. London: Routledge \& Kegan Paul Ltd. Munn, Nancy D. 1992. "The Cultural Anthropology of Time: A Critical Essay". Annual Review of Anthropology 21: 93-123. https://doi.org/10.1146/annurev. an.21.100192.000521.

Naumović, Slobodan. 2006. "On the heaviness offeathers, or what has culture got to do with the failure to establish an organic poultry production business in contemporary Serbia?" Etnoantropološki problemi 1 (1): 103-124. https://doi.org/10.21301/eap. v1i1.5. 
Naumović, Slobodan. 2013. Fields of Paradox: Three Case Studies on the Europeanisation of Agriculture in Serbia. Belgrade: Serbian Genealogical Center - Department of Ethnology and Anthropology, Faculty of Philosophy, Ethnological Series, Special Editions, Book 11.

Nedeljković, Saša. 2011. Kultura i nasilje - Pojmovi i paradigme. Kruševac: Baštinik. Pešić, Jelena. 2011. "Cultural Encounters in the Banking Sector of Serbia: The Case of Raiffeisenbank”. Etnoantropološki problemi 6 (1): 23-55. https://doi.org/10.21301/ eap.v6i1.1.

Pondy, Louis R., and Ian I. Mitroff. 1979. "Beyond open system models of organization”. In Research in Organizational Behavior: An Annual Series of Analytical Essays and Critical Reviews, edited by Barry M. Staw, 3-39. Greenwich: JAI Press.

Rajić Ćalić, Jovana. 2018. „Određene forme radnog vremena u Srbiji u svetlu Evropske direktive 2003/88 i uporednog prava“. Strani pravni život 62 (3): 181-196. https:// doi.org/10.5937/spz1803181R.

Ribić, Vladimir. 2007a. „Antropologija raspada Jugoslavije: o etničkom nacionalizmu“. U Antropologija postsocijalizma, uredio Vladimir Ribić, 216-243. Beograd: Srpski genealoški centar - Odeljenje za etnologiju i antropologiju Filozofskog fakuteta, Etnološka biblioteka 34.

Ribić, Vladimir. 2007b. Primenjena antropologija: Razvoj primenjenih antropoloških istraživanja u Velikoj Britaniji i Sjedinjenim Američkim Državama. Beograd: Srpski genealoški centar - Odeljenje za etnologiju i antropologiju Filozofskog fakuteta, Etnološka biblioteka 26.

Ribić, Vladimir. 2011. Politička antropologija i moderni svetski sistem. Beograd: Srpski genealoški centar - Odeljenje za etnologiju i antropologiju Filozofskog fakuteta, Etnološka biblioteka 54.

Rifkin, Jeremy. 2005. "The End of Work". Spiegel International. February 1, 2020. https://www.spiegel.de/international/jeremy-rifkin-on-europe-s-uncertain-futurethe-end-of-work-a-368155.html.

Rihtman-Auguštin, Dunja. 1970. „Kulturno-društveni okvir za istraživanje vrednota u ponašanju poduzeća“. Ekonomske studije 7: 5-19.

Rihtman-Auguštin, Dunja. 1972. „Četiri varijacije na temu kultura poduzeća“. Kulturni radnik 25 (3): 121-151.

Rihtman-Auguštin, Dunja. 1980. „Veliki sistemi i mali ljudi“. Arhitektura 3: 64-65.

Robbins, Stephen P. 2005. Essentials of Organizational Behavior. San Diego: San Diego State University.

Rosa, Hartmut. 2013. Social Acceleration. A New Theory of Modernity. New York Chichester: Columbia University Press.

Roza, Hartmut. 2019. Odnosi prema svetu u doba ubrzanja. Konture nove kritike društva. Novi Sad: Akademska knjiga.

Russell Hochschild, Arlie. 2003. The Managed Heart - Commercialization of Human Feeling. Berkley, Los Angeles and London: University of California Press.

Savić, Ljubodrag i Stefan Đerasimović. 2020. „Proizvodni potencijali i ostvarenja prerađivačke industrije Srbije tokom drugog talasa tranzicije“. Ekonomske ideje i praksa 37: 23-36. 
Sedgwick, Mitchell W. 2007. Globalization and Japanese Organizational Culture: An ethnography of a Japanese corporation in France. London and New York: Routledge.

Sinani, Danijel. 2012. „O proučavanjima porodične slave u Srbiji“. Etnološko-antropološke sveske 19 (8): 175-192.

Stojković, Jovan. 1986. „Proslava dana preduzeća“. Etnološke sveske 7: 33-38.

Tomlinson, John. 2007. The Culture of Speed. London: SAGE Publications Ltd.

Urban, Greg and Kyung-Nan Koh. 2013. "Ethnographic Research on Modern Business Corporations". Annual Review of Anthropology 42: 139-158. https://doi. org/10.1146/annurev-anthro-092412-155506.

Vučinić-Nešković Vesna and Vladimir Miokov. 2011. "Will Knjaz Miloš Belong to Foreigners? The Privatization and Image of Multinational Companies in the Serbian Media (2000-2005)". Etnoantropološki problemi 6 (1): 167-193. https://doi. org/10.21301/eap.v6i1.6.

Vučinić-Nešković, Vesna. 2003. "East-West Business Encounters in Serbia and Montenegro: How Serbian Repatriates from the West Experience their Business Environment". Sociologija 45 (3): 263-288. https://doi.org/10.2298/SOC0303263V.

Vučinić-Nešković, Vesna. 2010. "Intercultural Experiences of Hauzmajstor: A Case Study on Repatriate Entrepreneurship in Serbia”. Ethnologia Balcanica 14: 265-292.

Vučinić-Nešković, Vesna. 2011. "Negotiating Partnership: How Serbian Hauzmajstor Established a Buisness Relationship with Austrian Rustler”. Etnoantropološki problemi 6 (1): 87-118. https://doi.org/10.21301/eap.v6i1.3.

Vučinić-Nešković Vesna. 2012. "Repatriate Entrepreneurship in Serbia: Business Culture within Hauzmajstor". In Capitalism from Outside? Economic Cultures in Eastern Europe after 1989, edited by János Mátyás Kovács, and Violeta Zentai, 17-34. Budapest and New York: Central European University Press. http:/www.jstor.org/ stable/10.7829/j.ctt2jbp4q.6.

Vučinić-Nešković, Vesna. 2013. Metodologija terenskog istraživanja u antropologiji. Beograd: Srpski genealoški centar - Odeljenje za etnologiju i antropologiju Filozofskog fakuteta, Etnološka biblioteka, Posebna izdanja 10.

Wajcman, Judy. 2015. Pressed for Time. The Acceleration of Life in Digital Capitalism. Chicago: The University of Chicago Press.

Wright, Susan, ed. 2005. Anthropology of Organizations. London and New York: Routledge.

Zakon o državnim i drugim praznicima u Republici Srbiji. Službeni glasnik RS br. 43/01, 101/07 i 92/11. 12. januar 2020. http://www.paragraf.rs/propisi/zakon_o_drzavnim_i_drugim_praznicima_u_republici_srbiji.html. 
Bogdan Dražeta

Institute of Ethnology and Anthropology Faculty of Philosphy, University of Belgrade

Ljubica Milosavljević Department and Institute of Ethnology and Anthropology Faculty of Philosphy, University of Belgrade

Working Time and New Organizational Values as an Indicator of Acceleration of the Serbian Society During the Second Decade of the 21st Century: Anthropological Analysis

Based on the results of anthropological fieldwork conducted in 2015 and 2016, the paper aims to review the employees' experience regarding the process of the acceleration of time in the office of one multinational company in Belgrade. The scientific focus is placed on working hours and certain temporal boundaries that characterize it. The most significant outcome is that the experience of a given phenomenon is the result of the fact that time spent during the work increasingly pushes the private time of interlocutors to the point of complete usurpation. The process of the acceleration of time was analyzed at three levels based on the statements of fifty-six respondents. The methods used in this study were structured interviews, observation of daily activities and practices in the company's office, participant observation, survey on the demographic and socio-economic profiles of the interlocutors, and a field diary. The first level involved an analysis of business hours esteem; the second one was oriented towards studying the process and period of employees' adjustment to foreign colleagues; while the third level of analysis aimed to instruct employees' relationship to working hours before and after the experience of worink with foreign colleagues. This research design turned out to be the most appropriate if we keep in mind that the results of this study lean on the results of anthropological research from 2005, which aimed to review the experiences, strategies and expectations of 30 employed Belgraders of different work positions, work orientations and the length of careers in terms of working hours. Amonog these 30 respondents the blurring of the differences between business and private sphere of life has been detected due to the experience of working in a changed socio-economic and political context since 2000 and the beginning of the reform process within EU integration process, accompanied by the specific social acceleration. The continuation of these processes, with certain features that come as a result of another change in the country's political climate in 2012, therefore, are the key pathways through which the phenomenon of the acceleration of time in the modern Serbian society was observed on the example of a specific work/busi- 
ness community. Consequently, the acceleration of the Serbian society during the second decade of the 21 st century, on the example of employees in the office of one multinational company in Belgrade, showed that the experience of working hours and certain temporal boundaries that characterize it among employees is such that private time is almost completely usurped by work time. This can be read through working hours, which practically cease to have clearly defined temporal boundaries in life of most respondents. The performance of work tasks is placed in the service of merging the spheres of business and private life into one, within the wokring hours.

Key words: business anthropology, anthropology of time, social acceleration, working time, employees, multinational company

Les durées de travail et de nouvelles valeurs organisationnelles comme indicateurs de l'accélération de la société serbe au cours de la $2^{e}$ décennie $d u X X I^{e}$ siècle: analyse anthropologique

Le présent travail a pour l'objectif d'examiner le sentiment du processus d'accélération du temps chez les employés de bureau d'une compagnie multinationale à Belgrade et s'appuie sur les résultats d'une recherche de terrain menée en 2015 et 2016. Le travail est concentré sur la durée de travail et les limites temporelles caractéristiques qui définissent cette durée, alors que le résultat le plus important en est que ce sentiment du phénomène donné vient du fait que le temps passé au travail restreint de plus en plus le temps privé des interrogés, presque jusqu'au point d'une usurpation complète. Le processus d'accélération du temps a été analysé à trois niveaux à partir des réponses de cinquante six interrogés. Le premier niveau comprenait l'analyse du respect des horaires de travail; le deuxième était orienté vers l'étude du processus et de la période de son adaptation à des collègues étrangers; enfin le troisième niveau avait pour l'objectif de rendre compte du rapport des employés envers la durée de travail avant et après l'expérience de travailler avec des collègues étrangers. Un tel design de la recherche s'est avéré le plus approprié si l'on tient compte du fait que les résultats de cette recherche s'appuient sur les résultats d'une recherche anthropologique de 2005 qui visait à examiner les sentiments, les stratégies et les espérances quant aux durées de travail de trente Belgradois actifs, de profils de postes, d'orientations professionnelles et de longueurs de carrières différentes, chez qui a été détecté un brouillage des différences entre les sphères professionnelle et privée de leurs vies du fait de leur expérience de travail dans un contexte socioéconomique et politique changé depuis 2000 et le commencement du processus de réforme en vue d'adhérer à l'Union européenne qui a accompagné une accélération sociale spécifique. Le prolongement de ces processus, avec 
certaines composantes qui viennent aussi comme le résultat d'un changement de plus dans le climat politique du pays en 2012, sont pour cette raison, les thèmes clé à travers lesquels sera analysé le phénomène de l'accélération du temps dans la société serbe contemporaine sur l'exemple de la communauté de travail.

Mots clés: anthropologie professionnelle, anthropologie du temps, accélération sociale, durée du travail, employés, compagnie multinationale

Primljeno / Received: 6.04.2021

Prihvaćeno / Accepted: 5.05.2021. 